Journal of Social Sciences (COES\&RJ-JSS)

ISSN (E): 2305-9249 ISSN (P): 2305-9494

Publisher: Centre of Excellence for Scientific \& Research Journalism, COES\&RJ LLC

Online Publication Date: $1^{\text {st }}$ July 2017

Online Issue: Volume 6, Number 3, July 2017

https://doi.org/10.25255/jss.2017.6.3.584.602

\title{
Mindanao State University Tawi-Tawi College Faculty: Their Teaching Roles, Strategies, Problems, Prospects and Needs Kaberl O. Hajilan, Ph.D
}

Mindanao State University Tawi-Tawi College of Technology and Oceanography Bongao, Tawi-Tawi, Philippines

\begin{abstract}
:
The pursuit of excellence is a concern of Philippine higher education. In its quest for excellence, higher education in the Philippines must therefore be able to harness the potential of a person to the fullest extent, so that one may be able to discharge his roles in the society to the best of his ability. This study postulates that educational mangers of Institutions of Higher Education utilize the roles of educators as architect, composer, facilitator, friend, futurist, informant, manager, model, monitor, and student in order to attain quality teaching and learning, efficiency and effectiveness in carrying out their respective mandates. The main objective of the study was to assess the teaching roles, strategies, problems, prospects and needs of educators in Mindanao State University in Tawi-Tawi using descriptive quantitative study. The researcher formulated and revised set of questionnaires for the purpose patterned from Zwaenepoel (1995), and Hajilan (1998). As a result, educators' role being performed during classroom activities was properly applied and these are ranked from highest to lowest, namely: facilitator, model, manager, informant, architect, composer, futurist, friend, monitor, and student. Educators' strategies were innovative, flexible, evocative, and skill-oriented. The prospects, problems, and needs encountered by educators in teaching activities are as follows: financial support, school plant and facilities, books and instructional materials, faculty and staff development, and student development became obstacles and roadblocks to achieve efficient and effective teaching. Pearson correlation analysis indicated that demographic profile: age, sex, civil status, religion, monthly income, teaching experience in years, and highest educational attainment were significantly related to educators' performance in teaching. Stepwise regression analysis of independent variable revealed that teaching skills and strategies were significantly related to the performance of educators. Stepwise regression analysis on the role of educators resulted to three out of ten roles: as a student, architect and as informant being significantly related to their performance in college teaching at 0.05 and 0.01 , respectively.
\end{abstract}

Keywords:

teaching roles, strategies, teachers problems, prospects \& needs

\section{Citation:}

Hajilan, Kaberl O. (2017) ; Mindanao State University Tawi-Tawi College Faculty:Their Teaching Roles, Strategies, Problems, Prospects and Needs; Journal of Social Sciences (COES\&RJ-JSS), Vol.6, No.3, pp:584-602; https://doi.org/10.25255/jss.2017.6.3.584.602. 


\section{Introduction}

The pursuit of excellence is a concern of Philippine higher education. This is in line with its goal to produce qualified manpower needed to accelerate social and economic development and thus bring about improvement in the quality of life of the people. In its quest for excellence, higher education in the Philippines must therefore be able to harness the potential of a person to the fullest extent, so that one may be able to discharge his/her social, political, economic and spiritual roles in the society to the best of his/her ability. According to Arcelo as cited by Nagtalon (2001), in a society where each individual gives the best of himself/herself, there exists a working democracy, political stability, social solidarity, vibrant economy and just society.

An educator's role towards educational practice in college is one of the perennial issues in Higher Education Institutions (HEIs). In some instances the focus is on the progressiveness or conservativeness of educational practices, such that responses inevitably depend for their effectiveness on the role of educators' interest and participation. Few researches have been conducted to date on the role of educators using path analysis and discrepancy evaluation model towards theses educational practices, methods, performances and standards of teaching-learning activities.

In teaching, instructional leadership is faced not only with the problems of resistance to improve educational practices but also teachers' indifference in fulfilling their roles. Notwithstanding the fact that educators are adaptive to change, there are indications of resistance and indifference in their work environments. This educational phenomenon has troubled administrators and other educational officials. Even when educational managers use their most logical argument to support a program, there is still resentment or indifference to some educators, thus we need to evaluate.

To address this problem, this study was undertaken to develop and unify a set of measures that could be used to assess and evaluate the effectiveness of the roles of teachers in higher education institutions. Knowing the different roles of educators cannot solve the low rating of faculty, less effectiveness in teaching and weaknesses. More importantly, the need to assess and evaluate their strengths and weaknesses, their roes to be improved and what would give the best impact on student learning is the objective of the study. Nowadays, self-evaluation seems to be the cornerstone for progress and development in educational pursuit to attain academic excellence.

It was indeed the main concern of this study to provide leeway for the improvement, modification, and redirection of educators' roles in higher education institution by adopting the path analysis and discrepancy evaluation models.

\section{Statement of the problem}

This study endeavored to evaluate the role of educators in Mindanao State University at Tawi-Tawi. Specifically, the study aimed to find answers to the following questions:

1. What are the educators' attitudes toward their role?

2. What are the skills acquired by the educators in teaching-learning activities?

3. What is the level of performance of educators in performing their role?

4. Are there relationships between teaching skills, attitudes, and performance of educators?

5. What are the problems encountered by educators in fulfilling their role? 
Aquino (1989) mentioned that as educators, "we want the highest conceivable excellence in the activities crucial to our effectiveness and creativity as a society. We need excellent educators, mentors, administrative leaders so as to ensure that education providers will continuously provide quality educations to the students. The performance and future of our society depend upon a pervasive and almost universal striving for good performance.

Educators in the higher education institutions consciously or unconsciously practice and perform their teaching roles in their respective filed and departments. While educational managers everywhere get things done by evaluating, monitoring, supervising, planning, leading and controlling their operations, the researcher believe that educators in higher education institution should realize the importance of these roles in their day to day activities as mentors. Teachers' role is crucial in shaping the minds of the learners. Teachers should construct curricula or learning materialsthat promote the cultural resources of the students. This suggests not only taking the languages, histories, experiences, and voices of the students seriously, but also integrating what is taught in schools to the dynamics of everyday life Rage and Hope as cited by Giroux (1999). Heller (1998), stressed that any systematic approach to improving performance needs to challenge existing ways of working. Teams looking to improve must learn to generate their own tasks, tackle problems, agree on solutions, and implement their decisions with confidence.

\section{Methods}

The setting of the study was the Mindanao State University- Tawi-Tawi College of Technology and Oceanography, in the province of Tawi-Tawi, Autonomous Region in Muslim Mindanao. It involved seven colleges and three junior colleges under the College of Arts and Sciences.

This study was conducted in seven colleges in the main Campus as well as the three Junior Colleges under the College of Arts and Science Extension in the island Municipalities.The respondents of this study were college educators who were given loads from first to second semester academic year 2004-2005 for at least a minimum of six units. Those faculty members assigned in Preparatory High School, Science High School and Laboratory Elementary School who have been awarded collegiate ranks and have teaching loads were included as respondents of the study. The study was conducted in two Old Campuses, Bongao Campus, Bongao, Tawi-Tawi, and three junior colleges in different municipalities these were UngasMatata Junior College, Sibutu Junior College, and Mapun Junior College all in the province of Tawi-Tawi.

The researcher formulated and revised set of questionnaires for the purpose of collecting data for this study. This was patterned from Zwaenepoel (1995), Hajilan (1998), and Garcines (2004). The formulation of this questionnaire was to deduce information on demographic profile of respondents and their opinion on the performance of teaching habits; school factors such as instructional delivery, prospects, problem, and needs, financial support, school plant, and facilities, books and instructional materials, faculty, staff, and student development; educators' role in college teaching, teaching strategies like innovative, flexible, evocative, and skills-oriented.

The research instrument was pre-tested at the College of Arts and Science, College of Education and College of Agriculture, Central Mindanao University, among thirty- faculty 
member. The responses during the try-out were analyzed using the Statistical Package for Social Science (SPSS) reliability analysis. The reliability coefficient of the instruments was 0.87 which indicated that the research instrument was highly reliable.

For Likert-type questions (5-point scale) the weighted mean was used. The following points were assigned to measure the degree of the agreement of teaching habits; psychological characteristics; school factors; educators' role in college teaching; and educators' teaching strategies.

With the permission from the Office of the Mindanao State University Chancellor at Bongao, Tawi-Tawi, the researcher started gathering data from the seven colleges throughout Mindanao State University at Tawi-Tawi. It took the whole month of January 2005 to gather the necessary data from seven colleges in the island municipalities where College of Arts and Sciences Extensions located. For the island Municipalities College of Arts and Sciences Extensions faculty respondents, questionnaires were sent through hired research assistant who spent two weeks to retrieve the responses. Primary data were collected through personal interview and administration of the questionnaire by the researcher.

All gathered data were summarized, translated and analyzed sung the Statistical Package for Social Science (SPSS) software. Descriptive statistics was used to describe the educators' role performance in college teaching at Mindanao State University Tawi-Tawi. Pearson Product Moment Correlation was used to determine the linear associations of the relationship between the selected variables and the performance of the educators in performing their roles of teaching. While one way analysis of variance (ANOVA) was employed to determine the significance among the means of the responses to the questionnaire from the group of respondents.

\section{Results and Discussions}

The data pertain to the personal demographic profiles and other information of the respondents on age, sex, civil status, religion, monthly income, appointment status, number of years in teaching and highest educational attainment; psychological characteristics on teaching habits, classroom activities using the same roles, performance in teaching strategies on innovative teachers, flexible teachers, evocative teachers, and skills-oriented teachers; and the various prospects, problems and needs confronting the educators such as financial support, school plant and facilities, books and instructional materials, faculty and staff development, and student development.

\section{Sex}

One hundred thirty faculty respondents participated in answering the questionnaire. There were seventy males (54\%) and sixty (46\%) females' faculty respondents.

Age

Findings reveal that majority of the faculty were old age due to retire few years from now. This means the respondents have vast of teaching experience.

\section{Civil Status}

Data shows that most of the respondents were married. It implies that they were committed to service because they have family to support. 


\section{Religion}

Most $(66.12 \%)$ of the respondents were Muslims.

\section{Monthly Income (Range)}

There were $(33.10 \%)$ respondents pegged to a salary range of $\mathrm{P} 11,000$ to $\mathrm{P} 15,000$ a month. The data shows that majority of the faculty were professor rank, followed by instructor level category. This means those faculty re-ranking and promotion schemes were so hard for them to get higher rank.

\section{Appointment status}

The permanent tenure got the highest portion $60 \%$. The results show that majority of the faculty were permanent. This implies that respondents were experienced educators and all met the standard requirement for permanent tenure.

\section{The number of years in the Teaching Profession}

A greater percentage $(36.15 \%)$ of the respondents had been in the teaching position below five years. The finding reveals that majority of the faculty was below five years teaching experience.

\section{Highest Educational Attainment}

Twenty-eight point forty six percent $(28.4 \%)$ of the respondents had Master's units. Finding show that majority of respondents earned Master's units. This means that the faculties are working for their next degree in order to upgrade their teaching efficiency and aspire for promotion.

\section{Teaching Habits}

The common educators teaching habits that are proliferated include dedication to service, loyal to their profession and willing to learn new teaching strategies. They were innovative, flexible, evocative, and skill-oriented

\section{Educators' Role in College Teaching}

The educator's respondents had categorically ranked the frequency of use of their roles in college teaching. They can act as facilitator, model, manager, informant, architect, composer, futurist, friend, monitor, and student.

\section{Educators' Performance in Teaching Strategies}

Innovative Educators

Innovative-educators have introduced different teaching strategies to make teaching learning fruitful and meaningful to their students. This type of innovation results to resourcefulness using different methods and techniques in teaching for the purpose of fast tracking the learners' development ability. According to Emery, W. G. (1996), teaching strategy in a form of oral dialogue format enabled all teacher innovators to describe what they did in the classroom. While Vegilind, E. M. and Jones, M. G. (1996) said that handsonand inquiry-based teaching methods is an effective teaching strategy.

The innovative educators' teaching strategies revealed that all statements are often practiced: "utilizing new methods and techniques" has a mean of 4.42; "effective and productive results" 4.35; "make use of the students' experiences" 4.05; "use actual 
situations in the community as a means of enriching curricular content" 4.25 ; "resourceful if teaching materials not enough" 4.28; "use indigenous materials available" 4.06; "try to recycle some items for use" 4.08; "never get discourage for lack of teaching aids" 4.12; "time always spent for investigating science" 3.82; and "invite students' curiosity and attention for discussion" 4.34. The Pooled Average Weighted Score of 4.17 means that educators often used these innovative teaching strategies.

According to Prado (1998) innovation in educational practice can take the form of new procedures, new technical aids, or a combination of both. This was enforced by Ramsden (2003) that teaching always involves attempts to alter students' understanding, so that they begin to conceptualize phenomena and ideas in the way scientists, mathematicians, historians, physicians, or other experts conceptualize them. While Forkett and Lumby (2003) stressed that in undertaking innovation, teachers may have little experience of school-based innovation.

Table1. Innovative Educators' Teaching Strategies

\begin{tabular}{|l|l|l|}
\hline INDICATORS: Innovative Educators & MEAN & DESCRIPTION \\
\hline Utilize new methods \& Techniques. & 4.42 & Often \\
\hline Are effective \& productive results. & 4.35 & Often \\
\hline Invite students' curiosity \& attention for discussion. & 4.34 & Often \\
\hline Are resourceful if teaching materials are not enough. & 4.28 & Often \\
\hline $\begin{array}{l}\text { Use actual situations in the community as a mean of } \\
\text { enriching curricular content }\end{array}$ & 4.25 & Often \\
\hline Never get discourage for lack of teaching aids & 4.12 & Often \\
\hline Try to recycle some items for use. & 4.08 & Often \\
\hline Use indigenous materials available. & 4.06 & Often \\
\hline Make use of the students' experience. & 4.05 & Often \\
\hline Time always spend for investigating sciences. & 3.82 & Often \\
\hline Pooled Average Weighted Score & 4.17 & Often \\
\hline
\end{tabular}

\section{The Flexible Educators}

The educators have to be flexible to all teaching learning activities, of course, in conjunction with standing academic policies, rules and regulations appurtenant to the students development as far as educational endeavor is concerned. Being flexible educators does not mean that they satisfy their interest sacrificing students learning and interest; they should address the needs of the students, problems, deficiencies, and lapses without bending the policies as prescribed by the university to that effect.

Responses of flexible educators to the statements in the questionnaire given to them are: "respect/provide individual differences" with a mean of 4.31 ; "provide integration of skills" 4.28; "enhanced varied learning areas" 4.32; "accept weaknesses and difficulty" 4.35 ; "invite experts to augment his teaching activity" 3.92 ; "promote student welfare" 4.38; "access to academic improvement" 4.47; "establish friendly environment among students" 4.42; "promote symbiosis learning" 4.33; love students as sons and daughters" 4.43. the highest mean was 4.43; and the lowest means was 3.92. The Pooled Average Weighted Score was 4.31. This indicates that this teaching strategy was often times adopted and they were flexible in their activity just to make their strategy effective and 
efficient, and therefore, educators were concerned and aware about the student development.

According to Seih as cited by Labay and Macarayan (1998) a Teacher must be flexible, interpersonally competent and concerned about career development. However, Greogrio (1996) pointed out that teachers must be flexible enough to allow alterations and interpretations to meet the circumstances brought about by the changing and unforeseen societal conditions.

Table 2. The flexible educators' teaching strategies

\begin{tabular}{|l|l|l|}
\hline INDICATORS: Flexible Educators & MEAN & DESCRIPTION \\
\hline Access to academic improvement & 4.47 & Often \\
\hline Love students as sons \& daughter & 4.43 & Often \\
\hline Establish friendly environment among students & 4.42 & Often \\
\hline Promote student welfare & 4.38 & Often \\
\hline Accept weaknesses \&difficulty & 4.35 & Often \\
\hline Promote symbiosis in learning & 4.33 & Often \\
\hline Enhanced varied learning areas & 4.32 & Often \\
\hline Respect/provide for individual differences & 4.31 & Often \\
\hline Provide integration of skills & 4.28 & Often \\
\hline Invite experts to augment his teaching activity & 3.92 & Often \\
\hline Pooled Average Weighted Score & 4.31 & Often \\
\hline
\end{tabular}

\section{The Evocative Educators}

The evocative educators always think of the prosperity of the students, develop their courage to make their studies successful, effective, and converge different concerns to awaken the interest of the learners in the light of their teaching activity. Provide avenues; broaden their view to achieve excellent grades as gauge for career development. Be participative and try making them feel the importance of being educative through effective teaching advocacy.

Evocative educators responded often to the ten statements in the following ways: The highest mean was 4.49, "show concern when there is distress or disaster"; and "elicit bilateral/two-way communication between students and teachers as the lowest mean of 4.08"; "elicit student participation" 4.38; "make use of experiences sharing among students" 4.29; "provide curiosity for latest discovery" 4.27; "tension-free during learning and examination process" 4.23; "arouse individual interest of students" 4.46; "provide solutions for problem encountered by students" 4.41; "patch short coming among students" 4.22; and "never give up of students' indifferences" 4.25. In general, the overall responses based on the Pooled Average Weighted Score were 4.30. This reveals that these teaching strategies are being performed often times, and the educators were really evocative in performing the strategies of teaching because they have a lot of activities.

According to Gregorio (1996) by creating a proper mental set, interest guarantees attention and paves the way for activity leading further activity.

Table 3. Evocative Educators' teaching strategies INDICATORS: Evocative Educators \begin{tabular}{l|l} 
MEAN & DESCRIPTION
\end{tabular} 


\begin{tabular}{|l|l|l|}
\hline & & \\
\hline Show concern when there is disaster or distress & 4.49 & Often \\
\hline Arouse individual interest of students & 4.46 & Often \\
\hline Provide solutions for problems encountered by the students & 4.41 & Often \\
\hline Elicit student participation & 4.38 & Often \\
\hline Make use of experiences sharing among students & 4.29 & Often \\
\hline Provide curiosity for fastest discovery & 4.27 & Often \\
\hline Never give up students' indifferences & 4.25 & Often \\
\hline Tension free during learning \& examination process & 4.23 & Often \\
\hline Patch short coming among students students \& & 4.22 & Often \\
\hline $\begin{array}{l}\text { Elicit bilateral/two-communication between } \\
\text { teachers }\end{array}$ & 4.08 & Often \\
\hline Pooled Average Weighted Score & 4.30 & Often \\
\hline
\end{tabular}

The Skills-Oriented Educators

This is one of the most appreciated and result oriented strategies as far as teaching is concerned. It is through this strategy that educators elaborate, expound, and apply authenticity of his methodologies. Educators to be skill-oriented have to be flexible, evocative and innovative. This means that they should be psychologists, philosophers, sociologists, and behaviorists.

The skill-oriented educators indicated their responses always to the three statements: "develop the ability to think analytically and reason logically" with a mean of 4.56; "encourage shy students to participate in any endeavors" 4.55; and "develop appreciation and sense of values" 4.50. the seven statements: "develop psycho-motor skills of the students" with a mean of 4.29; "develop critical thinking in them" 4.35; "develop students' potential and creativity" 4.45; "disagree students' ability" 4.34; "establish linkage for students' exposure and tour" 4.38; and "unlimited discussion for new ideas proliferation" 4.10 were responded often as revealed by its Pooled Average Weighted Score of 4.34. This indicated that the skills-oriented educators often applied those teaching strategies. It is noted that they always develop thinking ability, power reasoning, sense of value, and encourage the shy students to participate in the teaching learning activities. This means that students were benefited of this teaching activity as applied by skilloriented educators as reflected in their responses.

According to Gregorio (1996) the teacher must become skillful in providing for meaningful study materials, working with students on tasks of optional size and scope, and knowing the best distribution of learning activities. While O'donoghue, T.A., and Booker, R. (1996) stated that teacher education programs are often absent a connection between knowledge and skills taught in the classroom of the education school and their application in practice.

Table 4. Skills-Oriented Educators' Teaching Strategies

\begin{tabular}{|l|l|l|}
\hline INDICATORS: Skills-Oriented Educators & MEAN & DESCRIPTION \\
\hline Develop the ability to think analytically \& reason logically. & 4.56 & Always \\
\hline Encourage shy students to participate in any Endeavors & 4.55 & Always \\
\hline Develop appreciation \& sense of value & 4.50 & Always \\
\hline Develop Students' potential \& creativity & 4.45 & Often \\
\hline
\end{tabular}




\begin{tabular}{|c|c|c|}
\hline Lay down constructive ideas for developmental Thinking & 4.39 & Often \\
\hline Establish linkage for students' exposure \& tour & 4.38 & Often \\
\hline Develop students critical thinking in tem & 4.35 & Often \\
\hline Disagree Students' ability & 4.34 & Often \\
\hline Develop psycho-motor skills of the students & 4.29 & Often \\
\hline Unlimited discussion for new ideas proliferation & 4.10 & Often \\
\hline Pooled Average Weighted Score & 4.34 & Often \\
\hline
\end{tabular}

\section{Prospects, Problems, and Needs}

The problemsencountered by educators' at MSU Tawi-Tawi are presented. For the purpose of this study, the following comprised the problems that confronted the educators in the performance of their roles and responsibilities in teaching: financial support, school plant, and facilities, books and instructional material, faculty, staff, and student development.

\section{Financial Support}

The perception of the educators on the problems on financing and support in teaching activities are presented in Table 5. The educators perceived that they encountered serious problem on financial support with a Pooled Average Weighted Score of 3.62. they indicated that the serious problem that they encountered under this category was "the lack of budgetary allocation to support the teaching needs" (3.75); "there is procrastinating habit to release funds" (3.76); "slow procurement of needed books, supplies and equipment" (3.68); "inadequate incentive for the faculty" (3.55); "some curricular activities suffer due to no funds available" (3.72); "some overloads pay are not paid" (3.36); "other honoraria pay are given priority" (3.36). however, they encountered less serious problem on the "lack of concern in academic program" 3.26); "lack linkages with funding agencies and other NGOs" (4.40); and lack involvement of others in financial planning" (3.36). This means that these factors affected the teaching performance of educators. According to Lao, M.M (2001) states that a university administrator should not spend most of his time inside his plush or air-conditioned office; he must go out and establish linkages with local and international funding institutions to source funds intended for research and other relevant programs of the university. This supports the findings of Hajilan (1998) that the problems on financing and support are not confined to MSU-TCTO but in fact the major problem of State Colleges and Universities throughout the country. There is the perpetual lack of financing and support from the central government however the constituents of any public institutions of higher learning understand the perennial lack of government financial resources. The gripe of constituents of many state colleges or universities, primarily the faculty is the misuse of scarce public financial resources and this is coupled by the lack of transparency and the insensitivity of the people in the finance department considering that they are the main reason for the existence of these schools.

Table 5. Financial support

\begin{tabular}{|l|l|l|}
\hline INDICATORS: & MEAN & DESCRIPTION \\
\hline There is procrastinating habit to release the funds & 3.76 & Serious problem \\
\hline $\begin{array}{l}\text { Lack of budgetary allocation to support the teaching } \\
\text { needs }\end{array}$ & 3.75 & Serious problem \\
\hline Some curricular activities suffer due to no funds & 3.72 & Serious problem \\
\hline
\end{tabular}


Journal of Social Sciences (COES\&RJ-JSS), 6(3), pp. 584-602

\begin{tabular}{|l|l|l|}
\hline available & & \\
\hline $\begin{array}{l}\text { Slow procurement of needed books, supplies, \& } \\
\text { equipment }\end{array}$ & 3.68 & Serious problem \\
\hline Inadequate incentives for the faculty & 3.55 & Serious problem \\
\hline $\begin{array}{l}\text { Lack of linkages with funding agencies \& other } \\
\text { NGOs }\end{array}$ & 3.40 & Less Serious problem \\
\hline Other honoraria pay are given priority & 3.36 & Less Serious problem \\
\hline Lack of involvement of other financial planning & 3.36 & Less Serious problem \\
\hline Some overload pay are not paid & 3.36 & Less Serious problem \\
\hline Lack of concern in academic program & 3.26 & Less Serious problem \\
\hline \multicolumn{1}{|c|}{ Pooled Average Weighted Score } & 3.62 & Serious problem \\
\hline
\end{tabular}

According to Haworth and Conrad (1997), interviewees emphasized repeatedly that support the forms of financial aids, nontraditional course delivery formats, and career planning, and placement assistance consistently elevated the quality of students' learning experiences and favorably affected their personal and professional development.

\section{School Plant and Facilities}

The problems encountered by the educators on school plant and facilities. The educators responded that they encountered serious problem in the four statements: "lack of facilities and equipment for teaching learning activities" (3.74); not functional" (3.50); and "gates prone to get crashers and outsiders" (3.50). However, under this category, they expressed that they encountered "less serious problem" on the six statements: "lack of classrooms and buildings to hold classes" (3.11); "presence of dilapidated buildings and rooms" (3.33); "classrooms not conducive for learning and teaching" (3.21); "not all colleges given attention for infrastructure" (3.45); and "some departments share their offices to other offices" (3.05).

On the other hand, educators observed that they had "less serious problem" on School plant and facilities" with the Pooled Average Weighted Score of 3.38. This means that the school plant and facilities had less serious problem encountered but the management has to improve. This corroborates with findings of Hajilan (1998) that on the lack of facilities and equipment is a reality which higher authority at the said school should address immediately to improve the teaching learning situation.

According to Haworth and Conrad (1997) interviewees emphasized that adequate facilities and equipment- such as laboratories, theatres, computers, library resources, and essential field-related equipment and supplies- complemented and enriched students' efforts to learn advanced knowledge and techniques in their fields. This was enforced by Gregorio (1996) that improvement of curriculum program and quality of instruction of all levels by way of upgrading physical facilities, adoption of cost-saving instructional technology, and training and retraining of teachers and administrators.

Table 6. School Plant and Facilities

\begin{tabular}{|l|l|l|}
\hline VARIABLES & MEAN & DESCRIPTION \\
\hline $\begin{array}{l}\text { Lack of facilities \& equipment for teaching- } \\
\text { learning activities }\end{array}$ & 3.74 & Serious problem \\
\hline $\begin{array}{l}\text { Responsible officials have no interest in } \\
\text { improving facilities }\end{array}$ & 3.56 & Serious problem \\
\hline
\end{tabular}


Mindanao State University Tawi-Tawi College Faculty .....

\begin{tabular}{|l|l|l|}
\hline Some facilities not functional & 3.50 & Serious problem \\
\hline Gates prone to get crashers \& outsiders & 3.50 & Serious problem \\
\hline $\begin{array}{l}\text { Not all colleges given attention for } \\
\text { infrastructure }\end{array}$ & 3.45 & Less Serious problem \\
\hline Some facilities not in use for maximum utility & 3.37 & Less Serious problem \\
\hline Presence of dilapidated buildings \& rooms & 3.33 & Less Serious problem \\
\hline $\begin{array}{l}\text { Classrooms not conducive for learning \& } \\
\text { Teaching }\end{array}$ & 3.21 & Less Serious problem \\
\hline Lack of classrooms \& buildings to hold classes & 3.11 & Less Serious problem \\
\hline $\begin{array}{l}\text { Some departments share their offices to other } \\
\text { offices }\end{array}$ & 3.05 & Less Serious problem \\
\hline Pooled Average weighted Score & 3.38 & Less Serious problem \\
\hline
\end{tabular}

Books and Instructional Materials

The respondents disclosed that they have serious problem on the seven statements: "lack of textbooks and supplementary readings" (3.90); "books have not worn out, changed and old edition" (3.80); "inadequate office supplies intended for teaching" (3.72); "rooms are not safe to keep materials" (3.66); and "college library not equip with books of latest edition" (3.84). However, the respondents' responses to the three statements were less serious problem: "lack of teaching materials and aids for teaching" (3.38); "teaching materials are under standard" (3.25); and "no hands on computer set for students" (3.36). On the other hand, the Pooled Average Weighted Score was 3.65. This means that books and instructional materials are considered serious problem on current management. This supports the findings of Hajilan (1998) that the educational managers and faculty converged in the sense that they consider the problems of this category similarly serious.

According to Gregorio (1996) all instructional materials and devices must be prepared in advance. However, Alimo-ot (2003) stressed that in improving the quality of education there is a need to furnish more textbooks, references and instructional materials; selecting teachers more carefully, providing more helpful supervision of teachers and providing better financing for schools.

Table 7. The books and instructional Materials

\begin{tabular}{|c|c|c|}
\hline INDICATORS: & MEAN & DESCRIPTION \\
\hline Lack of textbooks \& supplementary readings & 3.90 & Serious Problem \\
\hline $\begin{array}{l}\text { College library not equip with books of latest } \\
\text { edition }\end{array}$ & 3.84 & Serious Problem \\
\hline $\begin{array}{l}\text { Books have not been worn out, change } \& \text { of old } \\
\text { edition }\end{array}$ & 3.80 & Serious Problem \\
\hline No overhead projector available for teaching & 3.76 & Serious Problem \\
\hline Inadequate office supplies intended for teaching & 3.72 & Serious Problem \\
\hline Rooms are not safe to keep materials & 3.66 & Serious Problem \\
\hline Other instruments for course not available & 3.66 & Serious Problem \\
\hline Lack of reading aids \& instructional materials & 3.38 & Less Serious Problem \\
\hline No hands on computer set for students & 3.36 & Less Serious Problem \\
\hline Teaching materials are under standard & 3.25 & Less Serious Problem \\
\hline Pooled Average Weighted Score & 3.65 & Serious Problem \\
\hline
\end{tabular}


Faculty and Staff Development

As gleaned from table 8, the educators responded serious problem to the two statements: "effective and efficient faculty and staff with no proper reward nor promotion" (3.58); and "delinquent faculty and staff with no punishment nor demotion" (3.73). The educators disclosed that the eight statements were less serious problem: "lack of faculty member in college/department" (2.98); "faculty are not trained in subject they teach" (2.98); "lack of cooperative group behavior and commitment to teaching" (3.05); staff development not given importance" 3.36; "no funds available for staff development" 3.49; "faculty grants are limited to selected few" 3.46; "faculty must scout his own scholarship" 3.46; and "training slots awarded to not qualified staff" 3.18. The Pooled Average Weighted Score was 3.33. This reveals that faculty and staff development is less serious problem in the present administration, hence the management must strengthen the faculty development program. This enjoins the findings of Hajilan (1998) that faculty and staff development should be rationalized and fair and this would imply that they should come up immediately with a comprehensive faculty and staff development program for the benefit of all those who are employed in this institution of higher learning. Everyone should be developed for the reason that a well-developed human resources will re-down to the benefit of the organization as a whole in the long run. This enforced by the statement of Lao, M.M (2001) that the amount of outside support for research training and faulty development poured into a university, in a sense, measures the extent of that university's credibility and reputation of an institution higher learning. This conformed by Mokhtari, K., Yellin, D., Bull, K., Montogomery, D. (1996) stated that in classroom, portfolios encourage teacher self-direction and reflection and from the basis for professional development

Table 8. Faculty and Staff Development

\begin{tabular}{|l|l|l|}
\hline INDICATORS: & MEAN & DESCRIPTION \\
\hline $\begin{array}{l}\text { Delinquent faculty \& staff neither punishment nor } \\
\text { demotion }\end{array}$ & 3.73 & Serious Problem \\
\hline $\begin{array}{l}\text { Effective \& efficient Faculty \& staff neither reward } \\
\text { nor promotion }\end{array}$ & 3.58 & Serious Problem \\
\hline No funds for staff development & 3.49 & Less Serious Problem \\
\hline Faculty grants are limited to selected few & 3.46 & Less Serious Problem \\
\hline Faculty must scout his own scholarship & 3.46 & Less Serious Problem \\
\hline Staff development is not given more importance & 3.36 & Less Serious Problem \\
\hline Training slots awarded to not qualified staff & 3.18 & Less Serious Problem \\
\hline $\begin{array}{l}\text { Lack of cooperative group behavior \& commitment } \\
\text { to teaching }\end{array}$ & 3.05 & Less Serious Problem \\
\hline Lack of faculty member in college/department & 2.98 & Less Serious Problem \\
\hline Faculty not trained in subject they teach & 2.98 & Less Serious Problem \\
\hline Pooled Average Weighted Score & 3.33 & Less Serious Problem \\
\hline
\end{tabular}

According to Tucker (1994) faculty with negative attitudes often lead to poor performance. While Duke (2002) stated that one of the main tools for judging and perhaps rewarding or punishing good or poor staff performance is performance appraisal and appraisal interview. However, Tam and Cheng as cited by Forkett and Lumby (2003) describe the nature of staff development as therefore different types of programs and activity which aim to empower teachers and administration to develop positive attitudes and beliefs about education and management, become more effective individuals and 
teams, be competent in teaching students and managing the school process, as well as helping the school adapt to its changing environment.

\section{Student Development}

The educators considered these statements serious problems on students "don't have good learning habits and attitudes" (3.58); "students show no respect to faculty" (3.97); and "lack of facilities and equipment for their development" 3.58. The Statements of less serious problem are: "lack of discipline and behavior among them" (3.43); "students lack interest in their studies due to faculty performance" (2.95); "students have poor influence and environment on study habits" (3.47); "students have no initiative for selfdevelopment" (3.49); "students seek transfer to other department due to environment" (2.78); "students transferred to other college due to poor teaching" (2.83); and "some development affected by students activities" (2.80).

Table 9. Students Development

\begin{tabular}{|l|l|l|}
\hline INDICATORS & MEAN & DESCRIPTION \\
\hline Students show no respect to faculty & 3.97 & Serious Problem \\
\hline Students don't have good learning habits \& attitudes & 3.58 & Serious Problem \\
\hline Lack of facilities \& equipment for their development & 3.58 & Serious Problem \\
\hline Students have no initiative for self-development & 3.49 & $\begin{array}{l}\text { Less Serious } \\
\text { Problem }\end{array}$ \\
\hline $\begin{array}{l}\text { Students have poor influence \& environment on study } \\
\text { habits }\end{array}$ & 3.47 & $\begin{array}{l}\text { Less Serious } \\
\text { Problem }\end{array}$ \\
\hline $\begin{array}{l}\text { Lack of discipline \& behavior among them } \\
\text { Students lack of interest in their studies due to faculty } \\
\text { performance }\end{array}$ & 3.43 & $\begin{array}{l}\text { Less Serious } \\
\text { Problem }\end{array}$ \\
\hline $\begin{array}{l}\text { Students transferred to other college due to } \\
\text { environment }\end{array}$ & 2.83 & $\begin{array}{l}\text { Less Serious } \\
\text { Problem }\end{array}$ \\
\hline $\begin{array}{l}\text { Some development affected by students' activities } \\
\text { Problem }\end{array}$ \\
\hline $\begin{array}{l}\text { Students seek transfer to other college due to poor } \\
\text { teaching }\end{array}$ & 2.78 & $\begin{array}{l}\text { Less Serious } \\
\text { Problem }\end{array}$ \\
\hline Pooled Average Weighted Score & 3.17 & $\begin{array}{l}\text { Less Serious } \\
\text { Problem } \\
\text { Problem }\end{array}$ \\
\hline
\end{tabular}

As shown in Table 9, the Pooled Average Weighted Score was 3.17. This means that the student development had less serious problem encountered, but nevertheless this should be looked upon to provide additional equipment and facilities for student development. This corroborates with the findings of Hajilan (1998) that the more demanding task at hand is how to assist the students in having good study habits, improve their interest in their studies and providing students with good influences and an ideal environment conducive to excellent learning.

According to Gregorio (1996) that the student reacts to the complex environment, which the schools provide, and the course of his experience in that environment, he not only learns subject matter, but also great complex of social habits, attitudes, and dispositions. However, Tianero (1996) cited that ideally, students be equipped with the ability to apply methods, tools and techniques learned in actual business situations; write clear, crisp and 
grammatically correct memoranda, letters and reports; to use computers, word processors and spread-sheet computations; show leadership potential and to apply ethical decision in difficult business situation.

There were four variables considered t describe educators' teaching strategies: innovative educators; flexible educators; evocative educators; and skills-oriented educators. The Pooled Average Weighted Score in each variable. The overall mean of Educators' teaching strategies during school year 2004-2005 was 4.285 with a description often. Skills-oriented educators received the highest rating with the pooled mean 4.340. The innovative educators were rated lowest. It goes to show that skills-oriented educators showed the best teaching strategies.

Table 10. Means of Educators' Teaching Strategies

\begin{tabular}{|l|l|l|}
\hline INDICATORS & POOLED MEAN & DESCRIPTION \\
\hline Skills-oriented Educators & 4.340 & Often \\
\hline Flexible Educators & 4.327 & Often \\
\hline Evocative Educators & 4.304 & Often \\
\hline Innovative Educators & 4.167 & Often \\
\hline $\begin{array}{l}\text { PERFORMACNE IN TEACHING } \\
\text { STRATEGIES }\end{array}$ & 4.285 & Often \\
\hline
\end{tabular}

Based on the results of the Teaching Strategies used as shown in Table 10 among the models using different variables of teaching strategies, roles and the educators' performance, results computed using the statistical techniques such as correlation, regression, standard deviation, mean and percentages that the teaching method is "excellent" rating with a mean of (4.67), teaching attitude and teaching habits have the same "excellent" rating with the mean of (4.57), and the same mean (4.57) for the latter. Teaching skills and educators" performance have the same "very good" with the mean of 4.34 and 4.29 respectively. This means that there is no need to modify or change the standards since the educators' performance was marked very good. The educators do not need to be retrained or terminated since the results of their teaching attitude, habits, and experience were excellent; and very good marks on teaching skills and methods.

Table 11. Problems and Needs encountered by the educators relative to their roles in teaching performance

\begin{tabular}{|l|l|l|l|}
\hline INDICATORS & FREQ. & PERCENT & RANK \\
\hline PROBLEMS: & 23 & 17.69 & 1 \\
\hline Faculty \& Staff absenteeism \& tardiness & 20 & 15.38 & 2 \\
\hline Faculty must be sent to attend seminar & 18 & 13.85 & 3 \\
\hline Lack of dedication, loyalty \& motivation to college & 17 & 13.08 & 4 \\
\hline Security for school properties & 16 & 12.31 & 5 \\
\hline Sound housing \& benefits for teachers & 15 & 11.54 & 6 \\
\hline Plantilla items for contractual faculty and staff & 9 & 6.92 & 7 \\
\hline Dirty campus \& comfort rooms & 5 & 3.85 & 8 \\
\hline Salary increase & 4 & 3.10 & 9 \\
\hline Curriculum design & 3 & 2.31 & 10 \\
\hline Teachers are not prepared & 130 & 100 & \\
\hline \multicolumn{1}{|l|}{ Total } & & \\
\hline
\end{tabular}


Mindanao State University Tawi-Tawi College Faculty .....

\begin{tabular}{|l|l|l|l|}
\hline NEEDS: & 17 & 4.53 & 1 \\
\hline Develop sense of loyalty to service & 16 & 13.68 & 2 \\
\hline Audio-visual aids & 14 & 11.47 & 3 \\
\hline Library building \& textbooks & 11 & 9.40 & 4.5 \\
\hline Classroom, chair \& equipment & 11 & 9.40 & 4.5 \\
\hline Internet connection to every college & 9 & 7.69 & 6 \\
\hline Students' exposures & 8 & 6.84 & 7 \\
\hline Additional qualified faculty \& staff & 6 & 5.13 & 9 \\
\hline Safe environment to hold classes & 6 & 5.13 & 9 \\
\hline Administration building & 6 & 5.13 & 9 \\
\hline Standardization of study & 4 & 3.42 & 11 \\
\hline Good facilities & 3 & 2.56 & 13 \\
\hline Wise use of funds & 3 & 2.56 & 13 \\
\hline On time overload pay & 3 & 2.56 & 13 \\
\hline Free yearly executive check up & 117 & 100 & \\
\hline
\end{tabular}

The most common problem met by the respondents was "faculty and staff absenteeism and tardiness "rank no.1)". Ranked no. 2 problem was "faculty must be sent to attend seminars". Problem on lack of dedication, loyalty and motivation to college or department ranked no. 3. Security for school properties ranked no.4. Some respondents identified sound housing and benefits for educators as rank no.5. Plantilla items for contractual faculty and staff rank no. 6 . Ranked no. 7 was the dirty campus and comfort rooms. Some of them mentioned that salary increase rank no.8. Curriculum design rank no.9; and ranked no. 10 was teachers are not prepared.

The most immediate needs of educators are: develop sense of loyalty to service rank no.1. the second in rank was audio-visual aids. Library and textbooks ranked no. 3. There were two needs for rank no. 4: classrooms, chairs, and equipment; and internet connection among colleges. The students' exposure ranked no.5. There is also a need of additional faculty and staffs rank no.6. There were three needs for rank no. 7: safe environment to hold class; standardization of study; and administration building. Good facilities ranked no. 8; wise use of funds; overload pay; and free yearly basic executive checkup ranked no. 9 .

According to Nagtalon (2001) quality and excellence are at stake when there are assertions that graduates lack the competencies needed in their choses vocations or when majority of the graduates who take the Professional regulation Commission's Examination fail. This is of course a product of complex confluence of factors like provision of well qualified faculty, infrastructure, facilities and financial resources. This was supported by Tianero (2001) stating that faculty published researches, books and professional articles make graduate education strong and academically excellent. Excellence in graduate in education requires a facilitating research environment, extensive libraries, well-equipped laboratories, sophisticated computer capabilities and publication office or a university press.

\section{Summary}

This inquiry intended to analyze and determine which among the variables demographic profile, teaching habits, were the best predictors of the educators' performance in college 
teaching. Data were taken from the college faculty of MSU Tawi-Tawi. The study was conducted in ten colleges including the extension classes at the different municipalities of Tawi-Tawi province. Data were gathered through survey questionnaire which was valid and reliable with an alpha coefficient of $=0.87$ reflecting high reliability. This was tested to college faculty of Central Mindanao University, Musuan, Bukidnon.

There were 130 college faculty of MSU Tawi-Tawi who were the respondents of the study. Descriptive statistics was used to describe the educators' performance the teaching habits, attitude and skills. Multiple Stepwise regression analysis was used to determine the variation of variables influencing the educators' performance in college teaching.

The Following were the findings of the study:

1. The highest percentage $(25 \%)$ of the total respondents was between ages 50 and above. The lowest percentage $18.43 \%$ of respondents had ages between 20-29 years old. Of the seven and three extension classes of MSU Tawi-Tawi, more than one -half of the respondents were males $53.85 \%$ and female $46.15 \%$. Majority of the respondents were married $63.11 \%$, single $32.31 \%$, widow $3.10 \%$ and separated $1.54 \%$. Majority of the respondents were Muslim 62.12\%, followed by Roman Catholic, Protestant, And SDA, $22.31 \%, 6.15 \%$ and $3.1 \%$, respectively, and the least under other category religion was $1.54 \%$. most of the respondents had a salary range between P11,000-15,000 a month (32.31), followed by P6,000-10,000, P16,000-20,000 and P21,000-25,000 (31.54\%, $23.11 \%$, and $10.77 \%$ ), respectively; and the least was P26,000-30,000 (2.31\%). Majority of the respondents were permanent at $60 \%$, next to contractual $28.46 \%$, followed by provisional $6.9 \%$ and last, casual at $4.61 \%$. The Highest percentage that served the college below years of teaching experience was $(36.15 \%)$, next above 20 years $(24.92 \%)$, followed by $10-15(17.69 \%), 15-19$ years $(10.77 \%)$, and the least was $6-9$ years $(8.46 \%)$. The highest percentage on educational attainment of the respondents with master's units (28.46\%), next with Master's holder (25.38), followed by Baccalaureate degree holders (22.31\%), PhD. Units only (20.77\%), and the least was PhD holders $3.10 \%$.

2. The indicators on teaching habits, attitudes, perception on teaching loads, perception on educational managers, strategies as innovative, flexible, evocative, skills-oriented educators revealed good results of Pooled Average Weighted Mean Score (4.57, 4.58, $4.43,4.10,4.17,4.31$, respectively.

3. The respondents enumerated the encountered problems and needs for those not reflected in the questionnaire of this study. The most pressing problems and needs are: for problems - faculty and staff absenteeism and tardiness; faculty must be sent to attend seminar; lack of dedication, loyalty and motivation to college; school property security; sound housing benefits to teachers; Plantilla items for faculty and staff; dirty comfort rooms and campus; salary increase rank no.8; curriculum design; and teachers are not prepared. The immediate needs were: develop sense of loyalty to service; audio-visual aids; library building and books, faculty room, classroom, and equipment; and internet connection to every college; student exposures; additional qualified faculty and staff: safe environment to hold class administration building; and standardization of study; good facilities; wise use of funds; overload pay; and free yearly basic executive checkup.

\section{Conclusions}

1. The level of teaching habits of educators in their identified roles is very high as indicated by the computed Pooled Average Weighted Mean of 4.57 
2. The level of performance of educators in the fulfillment of their teaching role is relatively high as indicated by the computed Pooled Average Weighted Score of 4.39. This means that educators have really often performed their teaching roles. It is also significantly existed when educators' role was correlated with teaching efficiency using different strategies.

3. As to the role of educators in teaching learning activity that influence their teaching performance have good results as reflected by computed Pooled Average Weighted Score of 4.34. This means that educators' role had influence the teaching performance.

4. The problems encountered by the educators while undergoing teaching are as follows: faculty and staff absenteeism and tardiness; faculty must be sent to attend seminars; lack of dedication, loyalty and motivation to service; school property security; sound housing and benefits to teachers; Plantilla items for faculty and staff; dirty campus and comfort rooms; salary increase; curriculum design; and teachers are not prepared. The needs were: develop the sense of loyalty to college; audio-visual aids; library building and textbooks; faculty room, classroom, equipment and chairs; internet connection to every college; students exposures; additional qualified faculty and staff; safe environment to hold class; administration building; good facilities; standardization of study; overload pay; and free yearly basic executive checkup.

\section{Recommendations}

1. The school officials and educational managers should come up and design strategies/programs to improve and enhance the educators' teaching habits and thereby develop excellent attitudes towards teaching performance.

2. Every college within the University must provide and strengthen the academic promotion and recruitment unit for the junior faculty and incoming ones.

3. The school head should issue an order to this effect requiring all educational managers and faculty to give full support and cooperation to the said program of the unit. The department chairmen must be vigilant and make meticulous observation about their faculty who, they feel, need to be helped to improve their teaching habits, attitudes, skills, and methods.

4. The teaching habits and attitudes should be enhanced and addressed to make them academically prepared.

5. Educators of the different levels may use the data generated from this study be it in tertiary, secondary or elementary to improve and uplift quality education. Knowing the fact that teaching habits, skills, and methods influence the educators' performance the teaching attitudes and habits be developed among the teaching personnel.

6. School officials and educational managers and all sectors of education should seek and solicit the involvement and participation of every concerned individual in the proliferation and development of excellent teaching habits and attitudes among educators. One way of proliferation this endeavor is making it regular agendum for every meeting to be called by the department, college or office.

7. School administration must provide and consider the basic needs of educators in order for the teaching learning activity to be fully enhanced and become staff-of the-art performance in teaching.

8. Further research is recommended to establish/include other variables not included in this study. 


\section{References}

Aquino, G.V. (1989). Principles and Methods Of Effective Teaching. Valenzuela, Metro Manila;.24 K Printing Company, Inc.

Barrido, E.L. Reomero, P.R., AndTianero, L.C. (Ed.) (2002). Graduate School Student's Council.Central Mindanao University, Musuan, Bukidnon. 3 (1).,Pp.38-39

Ben-Peretz, M. (2001). The Impossible Role of Teacher Educators In A Changing World. Journal of Teacher Education. 52 (6), Pp.90-111

Berg, H.And M. Ferbu.(2000). Men and Women Graduate Students. Journal Of Higher Education 54 (6),Pp.49-50

Cutance, P. 1995. Frameworks For Research On The Effectiveness Of Schooling. Edited By David Reynolds, Studying Effectiveness. Great Britain. Taylor and Francis

(Printers) Ltd.

Duka, C.D. (1999). Historical, Political, and Legal Foundation Of Education. Quezon City, Philippines: Phoenix Publishing House, Inc.

Duke, C. (2002). Managing the Learning University.Srhe and Open University, Celtic Court, 22 Ballmoor, Buckingham, Mk18 Ixw

Franco, E.A. (1994). Educational Planning: Center for Development, Management \& Productivity Manila, Philippines: Kalayaan Press Marketing Ent., Inc.

Forkett, N.And Lumby, J. (2003).Leading and Managing Education. 6 Bonhill St., London: Paul Chapman Publishing. A Sage Publishing Company.

Franco, E.A. (1994). Educational Planning: Center For Development,

Management \& Productivity

Glatter, R. 1989. Educational Instruction and Their Evaluation: Managing The Boundaries: Philadelphia. Milton Keyne Open University Press.

Gregorio, H. C. (1996). Principles and Methods of Teaching.Revised Edition.Garotech Publishing. $1172^{\text {nd }}$ St., Bitoon Circle, Barangay Commonwealth, Qc

Gregorio, P.B. (1988). Factors Affecting the English Performance Among College Freshmen.Unpublished Master's Thesis. Central Mindanao University, Musuan,

Bukidnon Philippines

Hawroth, A. and Bryan, R. A. 1998. Emblems of Quality In Higher Education:

Developing And Sustaining High-QualtiyProgrammes. Needham Heights, Ma: AllynAnd

Bacon. A Viacom Company

Householder, D.L.And Boser, R. A. (2004). Assessing the Effectiveness of TheChange to Technology In Technical Education. Internet Http://Www.Yahoo.Com Labay, T. And Macarayan, N.A. (1998). Teachers' Perceptions towards the Implementation of The In Selected Nhs of Bukidnon. Graduate School Journal 1 (1),Pp.115, Cmu Graduate School Journal, Musuan, Bukidnon

Lariosa, E.A. (2001). Some Roadblocks to Academic Excellence In Our Schools. In: Achieving Excellence in Research, Extension, And Instruction. Pal, S.K. (Ed.).

2001.Graduate School Student's Council. Central Mindanao University, Musuan, Bukidnon

Lao, M.M. (2001). The Making Of A University. In: Achieving Excellence in Research,

Extension, And Instruction.Pal, S.K. (Ed.).2001.Graduate School Student's Council.

Central Mindanao University, Musuan, Bukidnon

Mason, T. (1996). Integrated Curricula: Potential and Problems.Indiana University. Journal of Teachers Education. 47 (4)

Morphet, E. L., Reller, T.L. And Roe., L. (1992). Education Organization \& Administration: Concepts, Practice, \& Issues. $4^{\text {th }}$ Ed., Englewood Cliffs, New 
Jersey: Prentice-Hall, Inc.

Nolledo, J.N. (1995). The Education Act Of The Philippines Annotated With Related Law Issuance, \& Other Matters. Manila Philippines: Rex Book Store.

Nagtalon, J.A. (2002). Realities and Challenges in Graduate School Education. In: Charting Our Course: Trends and Issues in Education For The New Millennium.

Orstein, A. C. (1990). Strategies for Effecting Teaching. New York: Harper Collins Publishing.

Pampanga, A.R. (2004). Strategic Management And Instructional Leadership. Educational Conference.Deped.Cagayan De Ora City, Philippines.

Prado, N.I. (1995). An Evaluation Of The $4^{\text {th }}$ Year Secondary School Math Program In

Mindanao.Unpublished Dissertation Phd College Of Education, Up Diliman, Quezon City

Rage and Hope.(2004). Role of Teachers. Internet Http://Www.Mydocument

Ramsden, P. (2003). Learning To Teach In Higher Education. $2^{\text {nd }}$ Edition. 11 New Fetter Lane, London: RouteledgeFalmer

Rees, W. D. (1999).The Skills of Management. $4^{\text {th }}$ Ed., London: International Thomson Business Press.

Seeley, A. (2004). Role of Teacher. Internet Http://Www.Yahoo.Com

Tanner, D., and Tanner, L. (1987). Supervision in Education: Problem \& Practice. New York: Mcmillan Co.

Tianero, W.T. (1985). A System Analysis of The Instruction, Research \& Extension

Program of Central Mindanao University.Unpublished Phd. Dissertation.UST, Manila,

Philippines

Tianero and Tianero.(2001). School Legislation. Cagayan De Oro City, Philippines: 22 Karats Printing And Publishing House

Willms, J.D. (1992). Monitoring School Performance: A Guide For Educators. Tatylon and Francis, Inc., 1900 Frost Road, Suite 101, Bristol, Pa, Usa: The Falmer Press.

Zwaenepoel, P.P. (1995). System Analysis in Education. $2^{\text {nd }}$ Ed., Manila, UST, Printing Office. 